\title{
AN EXPERIMENTAL STUDY OF SELF HEALING OF CRACKS IN CONCRETE USING SODIUM SILICATE CAPSULE
}

\author{
A. Manoj Prabahar*, R. Dhanya, N. Ganapathy Ramasamy, S. Dhanasekar \\ Department of Civil Engineering, SRM University, Kattankulathur, \\ Kancheepuram - 603203, Tamil Nadu, India. \\ *E-mail: manojprabahar.amp@gmail.com
}

\begin{abstract}
Crack in concrete structure is a major problem affecting the durability of the structures and which may lead to failure of the structure. Repair and rehabilitation of concrete building or structures is expensive and it is difficult to access the damage after completing the construction of the structure. The solution for this type of problem is selfhealing concretes. Capsule based self-healing concrete is a new type of method used to decrease the damage and increase the service life and performance of a concrete structure. Healing agent like sodium silicate being capsulated and introduced into the concrete while casting. To observe the self-healing mechanism in the concrete sample, cracks were induced in the concrete sample by three point bending test. The healing process of concrete sample was observed using ultrasonic non-destructive concrete tester (UX4600). Self-healing concept was developed from wound healing mechanism in human being, in which certain level of wound can heal by itself. Self-healing agents have the ability to improve the properties of concrete even after damage. Thus the main mechanism of self-healing is the reaction of sodium silicate with the calcium hydroxide present in the concrete to form crystal like substance.

Keywords: Self-healing, Sodium silicate capsules, Micro cracks, Cracks, Crack depth, Ultra sonic concrete tester, Durability.
\end{abstract}

(C) RASĀYAN. All rights reserved

\section{INTRODUCTION}

Concrete is considered as a durable, strong and relatively inexpensive and widely used construction material. Cracks in concrete can decrease the service life of a structure, even leads to failure of the structure. Generally, these cracks can occur at any time of its service life and some may leads to failure. Crack in concrete is due to thermal stresses plastic shrinkage, settlement, corrosion of reinforcement, drying shrinkage and weathering or even due to loading ${ }^{\mathbf{1}}$. Cracks caused by drying shrinkage or plastic shrinkage are due to externally applied loads. To avoid such cracks, concretes are combined with different types of reinforcement to resist the tensile stresses. Although there are methods to control cracks in concrete, it is impossible to prevent cracks completely in concrete.

Initially, micro cracks may be formed, which are formed due to external loading or other factors. Micro cracks in concrete also affect durability and indirectly reduces the tensile strength ${ }^{2}$. Such micro cracks may lead to major problems, even to a structural failure. Therefore, inspection and maintenance should be done frequently. Regular inspection and maintenance of structure is expensive. In such cases, automatic healing of cracks is more reliable. Self-healing (automatic healing system) is the possible solution. These systems may be broadly sorted into different categories ${ }^{3}$ :

(1) Bacterial encapsulation,

(2) Self-healing with self-controlled tight crack width,

(3) Chemical encapsulation,

(4) Chemical in glass tubes and

(5) Mineral admixtures

This Self-healing concept was developed from wound healing mechanism in human being, in which certain level of wound can heal by itself ${ }^{4}$. Self-healing through bacteria is possible through bacterial concrete or bio concrete ${ }^{5}$. In this paper, the self-healing mechanism of sodium silicate solution is discussed. Capsule based self-healing concrete is a new type of method used to decrease the damage and

Rasayan J. Chem., 10(2), 577-583(2017)

http://dx.doi.org/10.7324/RJC.2017.1021671 
increase the service life and performance of a concrete structure ${ }^{6}$. The concept of capsule healing is based on some self-healing agent like sodium silicate being capsulated and introduced into the concrete while casting. Capsules were prepared in a batch process. ${ }^{7}$ A new type of microcapsules for self-healing was prepared that contained silica gel as shell and oil as a core material ${ }^{8}$. Self-healing concretes have the ability to improve the mechanical properties of concrete even after damage. Different types of selfhealing agents have been investigated for their healing mechanism of cracks 9

Cracks were developed in the concrete specimen (prism) by using three point bending system ${ }^{10}$. The healing process of crack in concrete sample is observed by using ultrasonic non-destructive concrete tester (UX4600). The reaction which takes place in the healing mechanism is between calcium hydroxide present in the concrete and the sodium silicate to form crystal like substance which arrests the cracks ${ }^{11}$. Such recovery can occur independently ${ }^{12}$. The main objective of this study is to minimize the micro level cracks in the concrete and increase its durability. Therefore, these materials can be used to increase the durability of concrete structure without spending high amount of cost for repair and safety purpose.

\section{EXPERIMENTAL}

\section{Brief discussion about materials used}

Ordinary Portland cement of grade 53 conforming to IS 8112-1989 was used. Test results on various physical properties of cement are shown in table 1 . Sodium silicate $\left(\mathrm{Na}_{2} \mathrm{O}_{3} \mathrm{Si}\right)$, is also known as water glass or liquid glass. Various properties of sodium silicate are shown in Table-1.

Table-1: Property of cement and a sodium silicate solution

\begin{tabular}{c|c|c|c|c|c}
\hline S. No. & Properties of cement & Values & S.No. & Properties of $\mathrm{Na}_{2} \mathrm{SiO}_{3}$ & Values \\
\hline 1. & Specific gravity & 3.15 & 5. & Density & $2.63 \mathrm{~g} / \mathrm{cm}^{3}$ \\
\hline 2. & Initial setting time & $34 \mathrm{~min}$ & 6. & Melting point & $\begin{array}{c}1,087^{\circ} \mathrm{C} \\
\left(1,990^{\circ} \mathrm{F}\right)\end{array}$ \\
\hline 3. & Final setting time & $448 \mathrm{~min}$ & 7. & Refractive index $\left(\mathrm{n}_{\mathrm{p}}\right)$ & 1.51 \\
\hline 4. & Finess modulus & 7.4 & 8. & Solubility in water & $21.91 \mathrm{~g} / 10 \mathrm{ml}$ \\
\hline
\end{tabular}

In this study, river sand with fine aggregates of size less than $4.75 \mathrm{~mm}$ was used. The fineness modulus of fine aggregate was 2.46 and its specific gravity is 2.74 . The fineness modulus and specific gravity of coarse aggregates was 6.89 and 2.65 respectively. Clean water recommended by IS 456- 2000 was used. Water-cement ratio was 0.45 . The chemicals used to prepare capsules are sodium silicate solution, Zemac-400 powder, urea, ammonium chloride, polyurethane (PU) prepolymer and Formaldehyde solution.All the chemicals were used and stored at $25^{\circ} \mathrm{C}^{13}$. Sodium silicate is the core material used in capsules. When sodium silicate is added into concrete, a chemical reaction occurs with the calcium hydroxide, which is already present in concrete that binds the crack, making concrete more durable and act as a water repellent. This type of coating is known as silicate mineral point. Water, quartz sand and caustic soda is prepared in a tank, and then into a reactor, where the stream is passed to form sodium silicate solution.

$\mathrm{SiO}_{2}+\mathrm{NaOH} \rightarrow \mathrm{Na}_{2} \mathrm{SiO}_{3}+\mathrm{H}_{2} \mathrm{O}$

In alkaline solution sodium silicate is stable. Silicic acid is formed when the hydrogen ions reacts with silicate ions in acidic state, which when heated forms a gel which is glassy and hard substance. Sodium silicate solution helps to reduce porosity, when concrete is treated with it.

\section{Experimental investigation}

To analyze the healing process of crack in concretes, fifteen concrete beams $(10 \times 10 \times 50 \mathrm{~cm})$ with different percentage of capsules $(0,1.5,3,4.5$ and $6 \%)$ were prepared. The sodium silicate capsules were mixed with the conventional concrete mix and samples were prepared. After casting, the specimens were removed from the mould and left in water for curing for 28 days at normal temperature. Three point 
bending system were used to introduce the crack in the concrete beam (prism). In this test a specimen with round iron setup is placed on two parallel supporting pins as show in figure. The loading is applied in the middle by loading pin, so that crack is developed in the middle of the concrete specimen. Cracks were created by applying certain amount of load on the concrete specimen (beam) as shown in Figure-1.
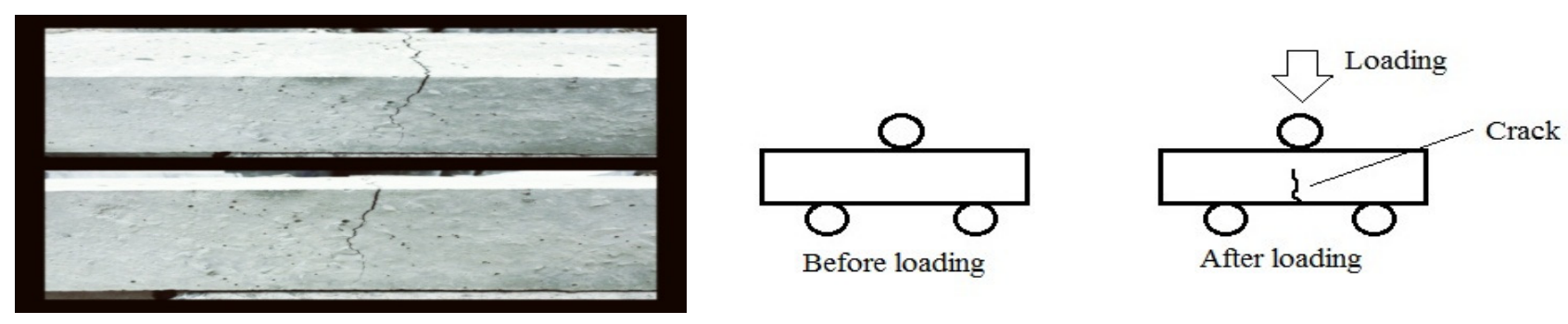

Fig.-1: Crack induced by three point bending test $\&$ Schematic diagram of loading system

\section{Ultra sonic pulse equipment}

The healing process of concrete sample was observed using ultrasonic non-destructive concrete tester (UX4600). This instrument is used to check the strength and quality of concrete. The quality of the concrete is evaluated by measuring the velocity of frequency (ultrasonic pulse) passing through it. Higher velocities indicate good quality and continuity of material, while slower velocities may indicate concrete with cracks or voids.

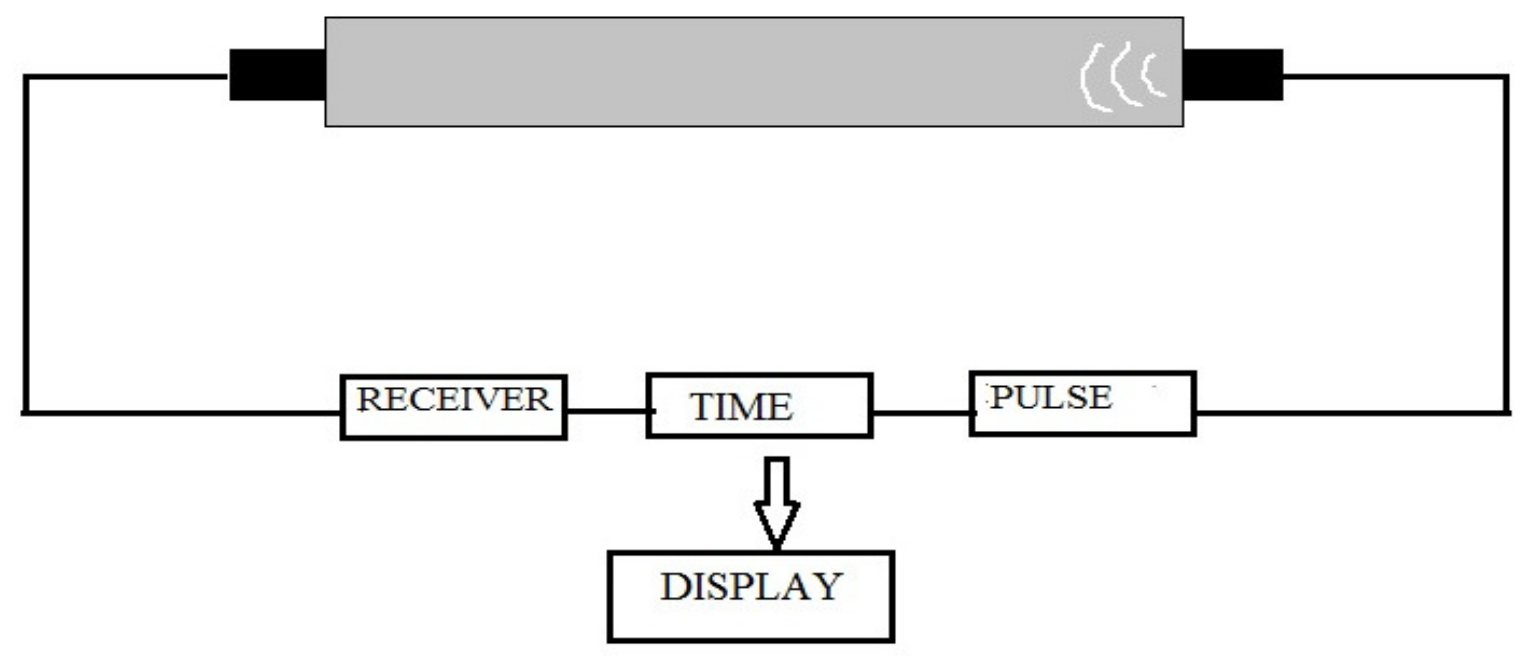

Fig.-2: Ultra Sonic Pulse Velocity Concrete Tester

Throughout this study, constant frequency was used. In order to provide a continuous and uniform pressure between concrete surfaces and transducers, the transducers were pressed towards concrete surface by hand. For an air-bubble-free contact between the concrete and the transducer, grease was applied in between them.

\section{Tc-To method (L-L method)}

By using ultra sonic pulse velocity, depth of the crack in the concrete can be measured in three different methods: (1) Tc-To method, (2) Delta method and (3) British standard method. Here Tc-To method is used to calculate the depth of crack in concrete.

$$
d=a\left(\sqrt{t_{c} / t_{o}}\right)^{2}-1
$$


Where, $d$ - Crack depth $(\mathrm{cm}), 2 \mathrm{a}$ - distance between receiver and oscillator $(\mathrm{cm}), \mathrm{t}_{\mathrm{c}}-$ transmission time (crack position) $(\mu \mathrm{s}) \mathrm{t}_{0^{-}}$transmission time (surface of health part) $(\mu \mathrm{s})$

In the Tc-To method, the transmission time $\left(\mathrm{t}_{\mathrm{o}}\right)$ and transmission time $\left(\mathrm{t}_{\mathrm{c}}\right)$ is measured by placing the receiver and oscillator at regular intervals $2 \mathrm{a}$ on the health part as well as the cracked surface of the concrete sample as shown in Figure-3. Depth of the cracks is calculated by the equation (2).
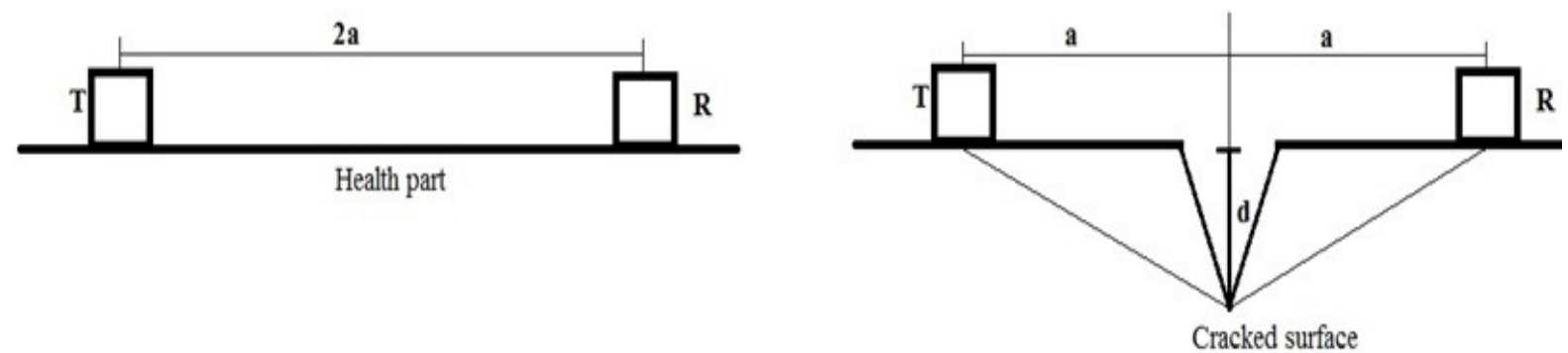

\section{Healing mechanism}

Fig.-3: Crack Depth Measurement Method

The mechanism carried out in the concrete beam is the calcium hydroxide present in the concrete reacts with the sodium silicate (healing agent). The reaction between calcium hydroxide and sodium silicate in the presence of water is given as:

$$
\mathrm{Ca}(\mathrm{OH})_{2}+\mathrm{Na}_{2} \mathrm{SiO}_{3}+\mathrm{H}_{2} \mathrm{O} \rightarrow \mathrm{x}\left(\mathrm{CaO} \cdot \mathrm{SiO}_{2}\right) \mathrm{H}_{2} \mathrm{O}+\mathrm{Na}_{2} \mathrm{O}
$$

Thus the self-healing mechanism is due to the reaction of calcium hydroxide with the sodium silicate to form crystal like substance which arrests the cracks.

\section{RESULTS AND DISCUSION}

To observe the healing rate of the cracks, ultrasonic non-destructive concrete tester (UX4600) was used to test the concrete samples at $3^{\text {rd }}$ day, $7^{\text {th }}$ day, $10^{\text {th }}$ day and $14^{\text {th }}$ day. The pictures of crack were taken. The pictures shows that the crack healed due to the healing agent present in the concrete sample. For better understanding of self-healing, frequency difference of various samples $(0 \%, 1.5 \%, 3 \%, 4.5 \%, 6 \%)$ is shown in Figures-5,6,7,8 and 9 respectively. These values are based on the three sample measurements in each percentage at different time duration (Days).

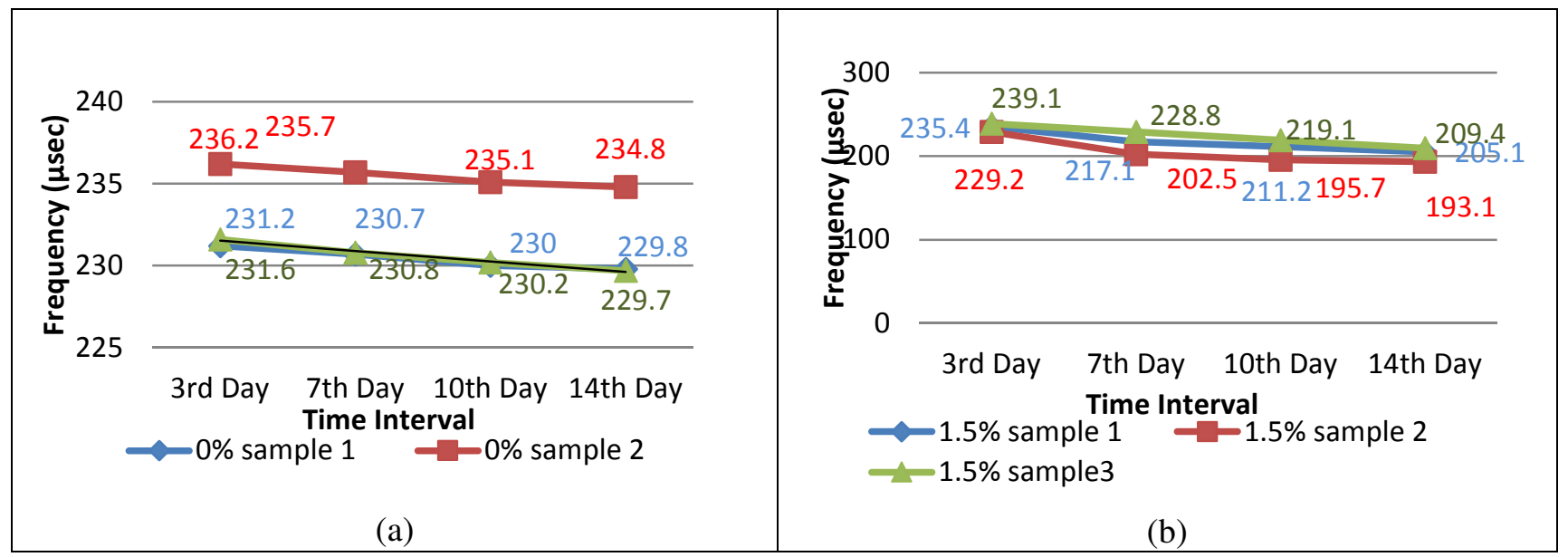

Fig.-4: (a) Frequency value of sample 0\% of capsules after cracking ( $\mu \mathrm{sec})$; (b) Frequency value of sample 1.5\% of capsules after cracking $(\mu \mathrm{sec})$ 
Concrete sample containing $4.5 \%$ showed a steady decrease in wave frequency. This indicates that the wave is passing through the concrete sample without any disturbance which means, the micro cracks in the concrete sample heals. For better understanding of self-healing, different percentages of capsules were introduced and the test results are shown in the Figure-7.

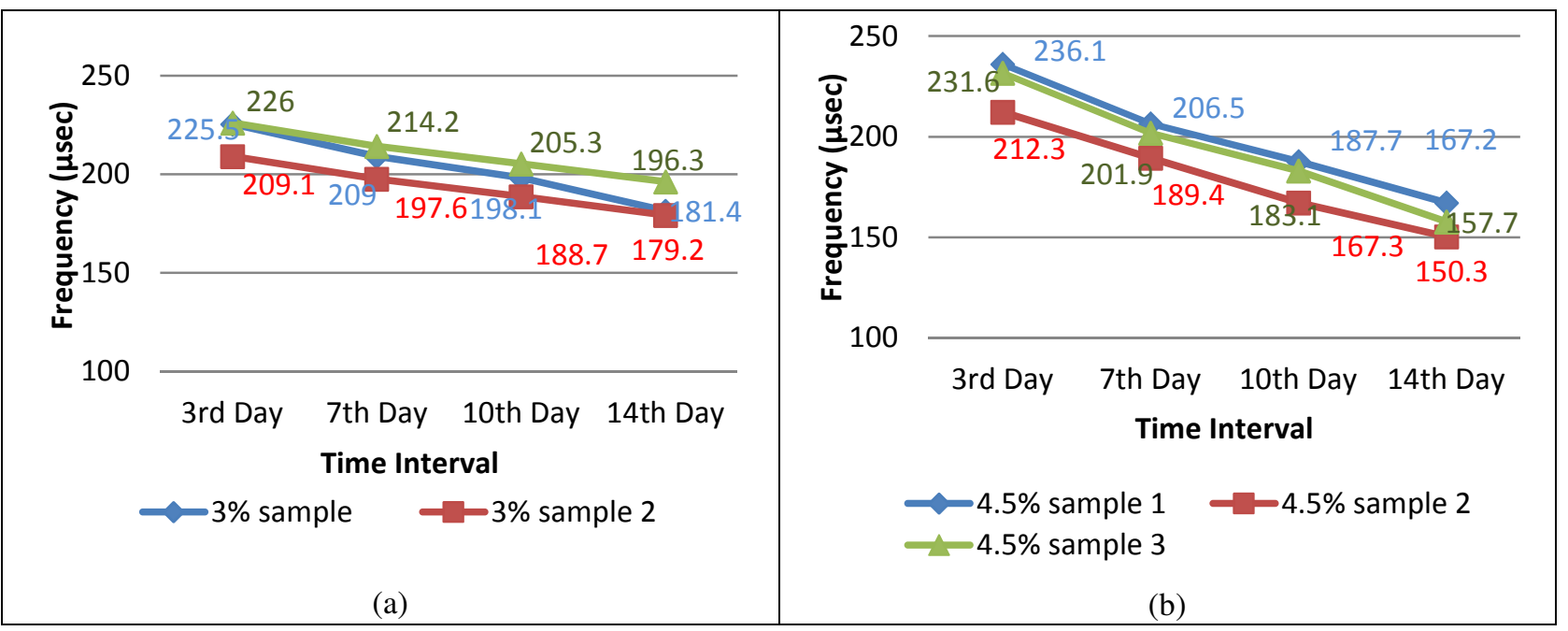

Fig.-5:(a) Frequency value of sample 3\% of capsules after cracking ( $\mu$ sec), (b) Frequency value of sample 4.5\% of capsules after cracking $(\mu \mathrm{sec})$

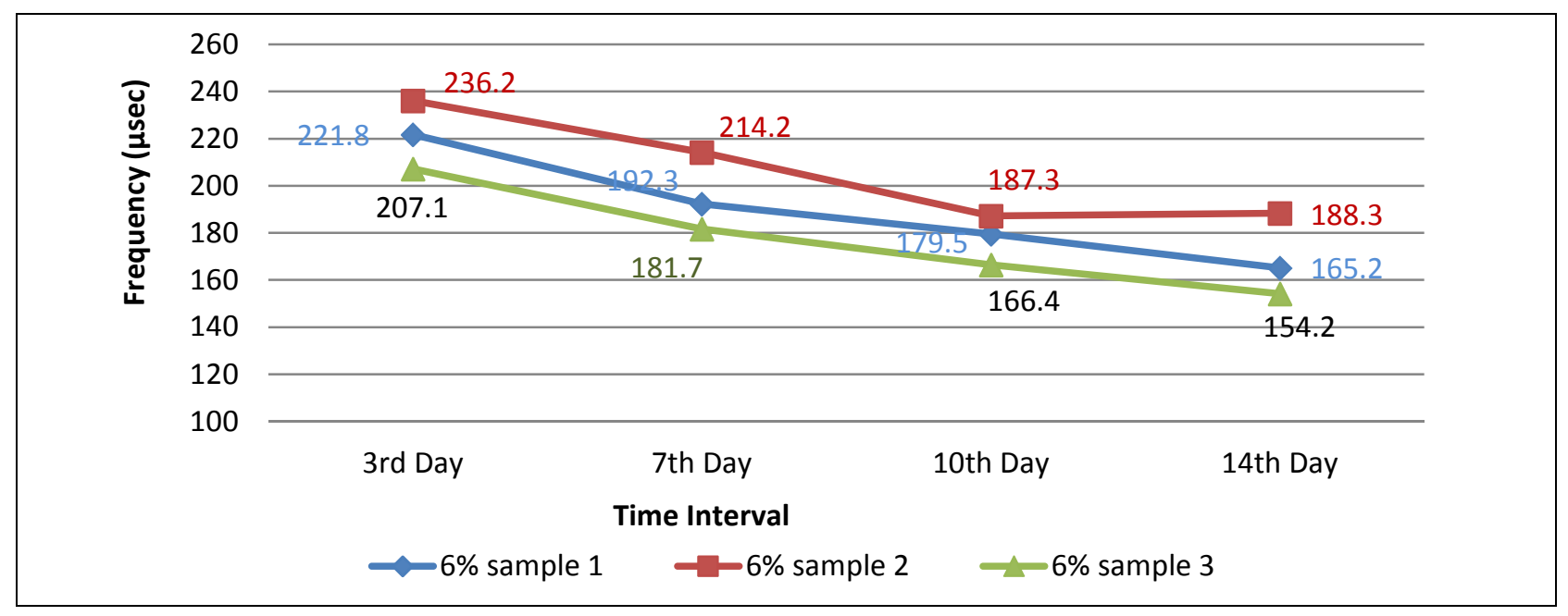

Fig.-6: Frequency value of sample with $6 \%$ of capsules after cracking $(\mu \mathrm{sec})$

Table-2: Frequency values of concrete sample

\begin{tabular}{|c|c|c|c|c|c|c|c|}
\hline \multirow[t]{2}{*}{ S.No. } & \multirow{2}{*}{$\begin{array}{c}\text { Load at which crack } \\
\text { developed } \\
(\mathrm{KN})\end{array}$} & \multirow[t]{2}{*}{$\begin{array}{c}\text { Capsule } \\
\text { percentage }(\%)\end{array}$} & \multirow{2}{*}{$\begin{array}{c}\text { Frequency value } \\
\text { before cracks induced } \\
(\mu \text { second })\end{array}$} & \multicolumn{4}{|c|}{$\begin{array}{l}\text { Frequency value after cracks induced } \\
(\mu \text { second })\end{array}$} \\
\hline & & & & $\begin{array}{c}3^{\text {rd }} \\
\text { Day }\end{array}$ & $\begin{array}{c}7^{\text {th }} \\
\text { Day }\end{array}$ & $\begin{array}{l}10^{\text {th }} \\
\text { Day }\end{array}$ & $\begin{array}{l}14^{\text {th }} \\
\text { Day }\end{array}$ \\
\hline 1 & 14 & 0 & 107.1 & 236.2 & 235.7 & 235.1 & 234.8 \\
\hline 2 & 14 & 1.5 & 106.2 & 235.4 & 217.1 & 211.2 & 205.1 \\
\hline 3 & 12 & 3 & 107.4 & 226.0 & 214.2 & 2.5 .3 & 196.3 \\
\hline 4 & 13 & 4.5 & 107.2 & 236.1 & 206.5 & 187.7 & 167.2 \\
\hline 5 & 14 & 6 & 108.2 & 236.2 & 214.2 & 197.3 & 188.3 \\
\hline
\end{tabular}


RASĀYAN J. Chem.

Vol. 10 | No. 2 |577 - 583 | April - June | 2017

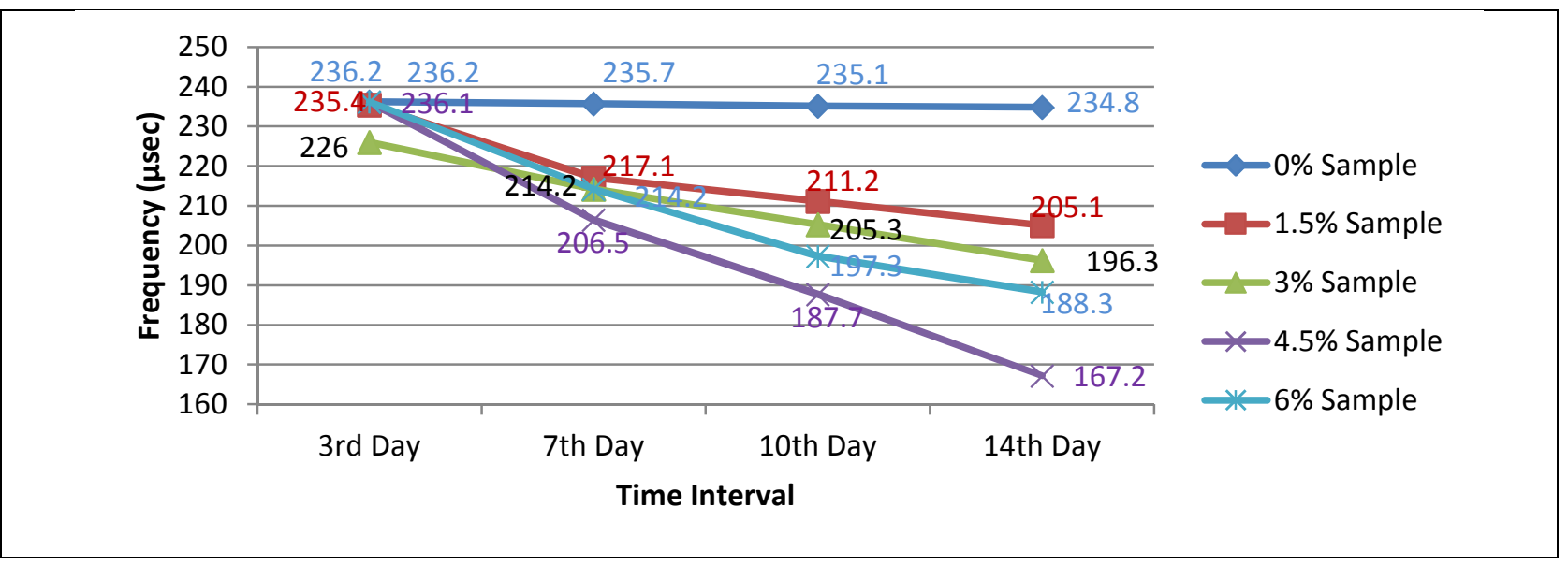

Fig.-7: Frequency value of samples with different percentage of capsules along with time duration $(\mu \mathrm{sec})$

Based on the slope variation in the figure 10 during the healing process, the rate of self-healing in concrete specimen with $4.5 \%$ capsules was higher in comparison with the other specimen. It can also be noted that the concrete specimen containing $4.5 \%$ capsules during the healing process is an indicator of higher healing rate when compared to all other specimen sample. By $\mathrm{T}_{\mathrm{C}}-\mathrm{T}_{\mathrm{o}}$ method, the crack depth obtained is shown in the Table-3.

Table-3: Depth of the crack in concrete

\begin{tabular}{c|c|c|c|c|c|c}
\hline S.No. & $\begin{array}{c}\text { Percentage of } \\
\text { capsules }(\%)\end{array}$ & $\begin{array}{c}\text { Depth after crack } \\
\text { induced }(\mathrm{cm})\end{array}$ & $\begin{array}{c}3^{\text {rd }} \text { day } \\
(\mathrm{cm})\end{array}$ & $\begin{array}{c}7^{\text {th }} \text { day } \\
(\mathrm{cm})\end{array}$ & $\begin{array}{c}10^{\text {th }} \text { day } \\
(\mathrm{cm})\end{array}$ & $\begin{array}{c}14^{\text {th }} \text { day } \\
(\mathrm{cm})\end{array}$ \\
\hline 1 & 0 & 7.92 & 7.92 & 7.91 & 7.92 & 7.92 \\
\hline 2 & 1.5 & 7.94 & 7.89 & 7.86 & 7.82 & 7.79 \\
\hline 3 & 3 & 7.96 & 7.9 & 7.84 & 7.81 & 7.78 \\
\hline 4 & 4.5 & 7.93 & 7.84 & 7.78 & 7.75 & 7.71 \\
\hline 5 & 6 & 7.94 & 7.88 & 7.85 & 7.81 & 7.78 \\
\hline
\end{tabular}

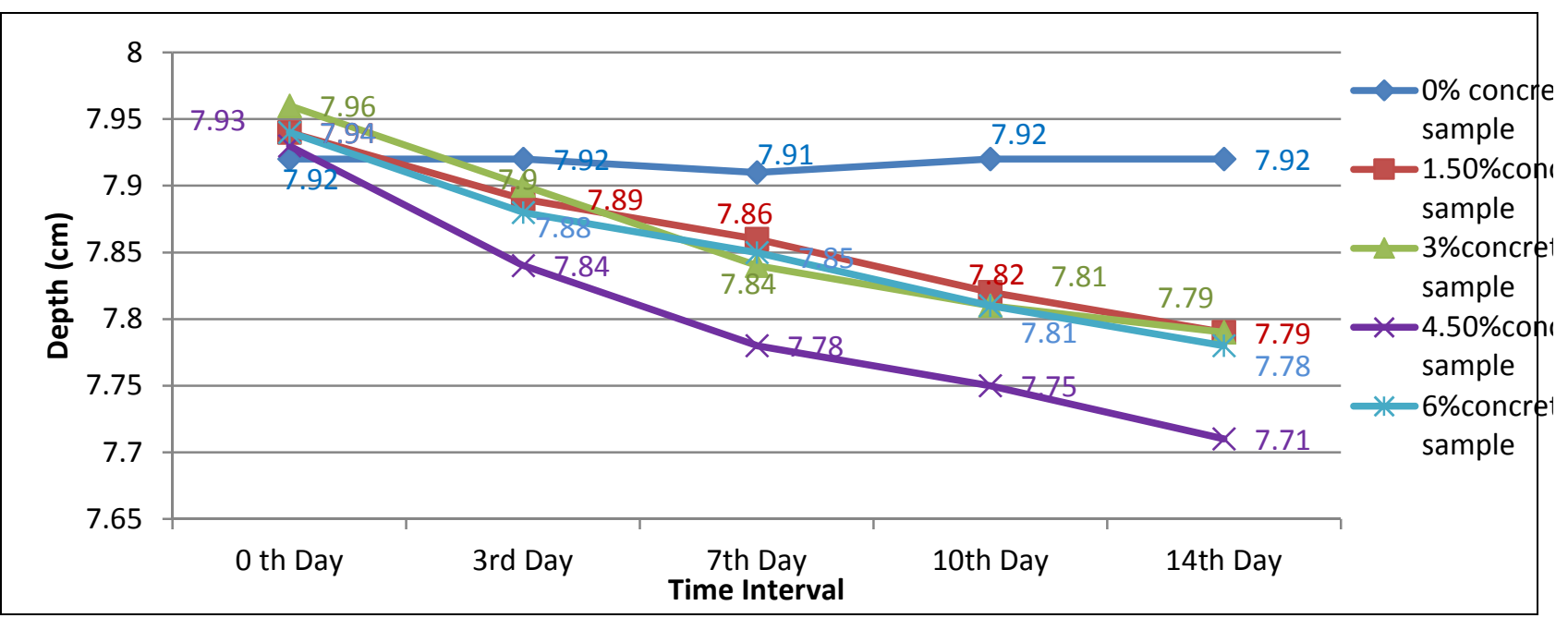

Fig.-8: Depth values of crack in concretes $(\mathrm{cm})$

Based on the slope in the Figure- 8 during the healing process of crack depth, the rate of healing in crack depth is higher in the $4.5 \%$ sample compared to other concrete samples. It can also be noted that the concrete specimen containing $4.5 \%$ capsules heals crack very fast when compared to other samples. Hence the healing rate is high at concrete sample containing $4.5 \%$ of capsules. 


\section{CONCLUSION}

Capsule based self-healing concrete is a new type of method used to decrease the damage and increase the service life and performance of a concrete structure, cracks were created by using three point bending system. Here the healing process of concrete sample was observed using ultrasonic non-destructive concrete tester (UX4600). The main mechanism of self-healing is the reaction of calcium hydroxide present in the concrete with sodium silicate solution and crystallization occurs. Such recovery can occur independently.

- Concrete sample containing $4.5 \%$ showed a steady decreasing in wave frequency which indicates that high percentage of healing occurs in it.

- The healing rate in concrete specimen with $4.5 \%$ capsules was higher in comparison with the other samples.

- The depth of the cracks in the concrete sample containing $4.5 \%$ capsules was initially $7.93 \mathrm{~cm}$ deep and its depth reduced to $7.71 \mathrm{~cm}$ depth $(22 \mathrm{~mm}$ healing) during healing process. Hence the healing rate is high at concrete sample containing $4.5 \%$ of capsules.

- The main advantage is that, it responds to multiple cracking at the same time and satisfactory recovery of durability and mechanical property.

- Therefore, these materials can be used to increase the durability of concrete structure without spending high amount of cost for repair and safety purpose.

\section{REFERENCE}

1. A. Mohsen, American Society of Civil Engineering, 4(2), 116(1999).

2. H W. Reinhardt and M. Joos, American Society of Civil Engineering, 33(7), 981(2003).

3. H M. Jonkers, Thijssen, Muyzer, Copuroglu, and Schlangen, E, American Society of Civil Engineering, 36(2), 230(2010).

4. Ehsan Mostavi, Somayeh Asadi, Marwa M. Hassan and Mohamed Alansari, Journal of Materials in Civil Engineering, 27(12), (2015).

5. Mian Luo and Chun Xiang Qian, Journal of Materials in Civil Engineering, 28(12), (2016).

6. James Gilford, Marwa, M. Hassan, Tyson Rupnow, Michele Barbato, American Society of Civil Engineering, 26(5),886(2012).

7. M M. Caruso, American Society of Civil Engineering, 2(4), 1195(2010).

8. H.M Jonker, Heron, 56, 1(2011).

9. B. Boh, and B.Sumiga, American Society of Civil Engineering, 55(3), 329(2008).

10. Haoling Huang, Guang Ye, American Society of Civil Engineering, 1(5), 532(2011).

11. P. Giannaros, A. Kanellopoulos and A Al-Tabbaa, Smart Materials and Structures, 25(8), 084005 (2016).

12. Souradeep Gupta and Harn Wei Kua, Journal of Materials in Civil Engineering, 28(12), (2016).

13. W. Zhong, and W. Yao, American Society of Civil Engineering, 22(6), 1137(2008).

14. S. Jacobsen and E J. Sellonold, American Society of Civil Engineering, 26(6), 869(1996).

15. B. Boh and B. Sumiga, American Society of Civil Engineering, 55(3), 329(2008).

16. A. Kanellopoulos, T S. Qureshi and Al-Tabbaa, Constr. Build. Mater., 98 780(2015).

17. J D. Rule, N R. Sottos and S R. White, Polymer, 48, 3520(2007).

18. A M. Anwar, K. Hattori, M. Ashraf and A. Goyal, International Journal of Civil Engineering and Technology, 2(5), (2007).

19. BS 1881: Part 203 (1986).

20. ASTM C 597-83(Reapproved 1991).

[RJC-1671/2017] 